\title{
ISR vượt mốc 100 công bố quốc tế chào đón năm mới
}

\author{
Nguyễn T. Thanh Huyền, Nguyễn Minh Hoàng, Hồ Mạnh Toàn \\ Trung tâm nghiên cứu xã hội liên ngành \\ Đại học Phenikaa
}

Hà Nội, 21-03-2021

Ngày đầu tiên của năm mới 2021 là thời gian để chúng tôi nhìn lại thành quả đạt được trong thời gian qua. Năm 2020 là một năm đặc biệt với Trung tâm nghiên cứu xã hội liên ngành (ISR) vì trung tâm đã vượt qua cột mốc công bố thứ 100 [1-104]

Thành lập vào ngày 1 tháng 8 năm 2017, trung tâm đã tồn tại được 1249 ngày. Trong suốt 41 tháng, các công bố của trung tâm được phát hành với nhiều thể loại, bao gồm các bài nghiên cứu gốc, bài quan điểm, bài rà soát tổng quan, sách và chương sách, bài đăng hội thảo và các bài blog khoa học uy tín lớn. Phân bổ số lượng các loại ấn phẩm được thể hiện ở hình 1.

\section{Hình 1. Công bố của trung tâm ISR theo loại ấn phẩm}

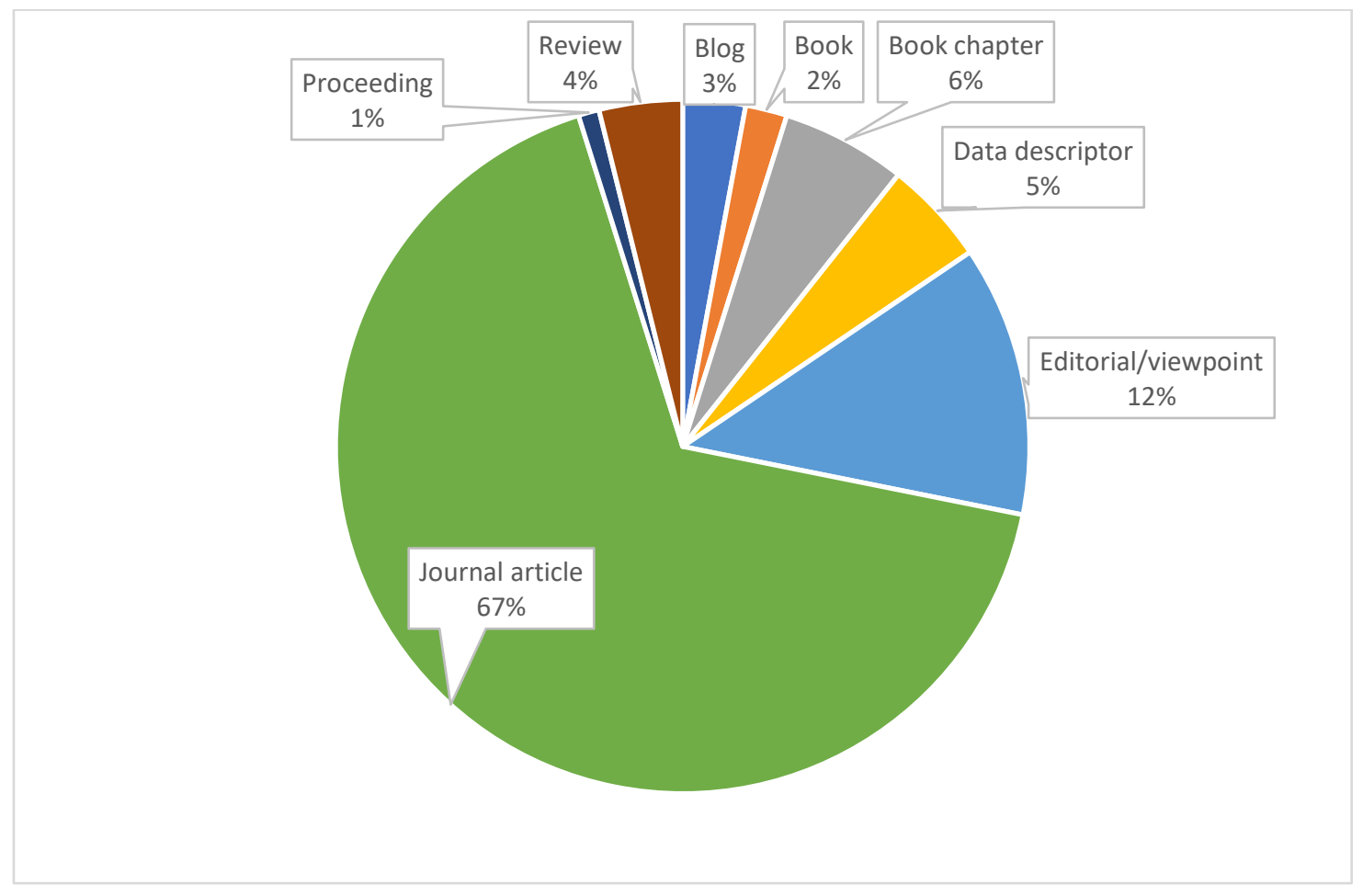

Sau quá trình đánh giá, chỉnh sửa bản thảo kĩ lưỡng, và hàng ngàn các bài báo cáo đánh giá phản biện, 69 nghiên cứu gốc đã được phát hành trên 35 tập san khoa học thuộc 21 nhà xuất bản, Elsevier, Nature Research, Springer, and Oxford University Press, Taylor \& Francis. 
Các bài quan điểm là loại bài với số lượng lớn thứ hai của trung tâm, bao gồm 13 công bố trên các tạp chí hàng đầu, như Nature, Nature Human Behavior, European Science Editing. Trung tâm ISR đã công bố hai bài đăng hội thảo và cả hai đều được đăng trên kỷ yếu của World Congress of Philosophy lần thứ XXIV. Kỷ yếu thuộc tập đăng cho Beijing World Congress vào năm 2018. Kể từ năm 2017, các tác giả của trung tâm ISR đã đóng góp bài viết cho các trang blog uy tín ba lần, trong đó hai bài trên Behavioural and Social Sciences Community được quản lý bởi Nature Research và một bài trên LSE Impact Blog của London School of Economics and Political Science (Đại học Kinh tế và Khoa học Chính trị London). Cuốn sách quan trọngThe Vietnamese Social Sciences at a Fork in the Road được phát hành vào năm 2019. Cuốn sách là bản hòa tấu dữ liệu về nghiên cứu KHXH\&NV tại Việt Nam trong giai đoạn từ 2008-2018. Chiếm 5\% tổng số công bố là các bài Khoa học Dữ liệu, được đăng trên hai tạp chí khoa học Scientific Data (Nature Research) và Data (MDPI). Trong hai năm gần đây, các thành viên của ISR đã bắt đầu viết các bài rà soát tổng quan thuộc ngành $Y$ học xã hội ( 2 công bố) và Kinh tế (1 công bố).

Thành quả đáng chú ý là các nghiên cứu viên thuộc trung tâm đã có 12 công bố với Nature Research ( 5 bài Nghiên cứu gốc, 2 bài Khoa học Dữ liệu, 2 bài Blog và 3 bài Quan điểm). Ngoài đó còn một niềm vui khác, sau nhiều sóng gió, gói phân tích Baysian được nhóm thiết kế dùng cho phần mềm R-studio đã được thông qua vào tháng 5 năm 2019 và hiện đang có sẵn trên CRAN (https://cran.r-project.org/package=bayesv). Con đường để đạt thành thành quả trên không hề thẳng tắp, trơn tru. Chỉ trong hơn ba năm, nhóm đã nhận được hơn 300 thư từ chối từ rất nhiều các tập san khoa học và nhà xuất bản thuộc hơn 10 chuyên ngành khác nhau, ví dụ như Kinh tế và Tài chính, Giáo dục, Khoa học môi trường, Khoa học chính trị, Nghiên cứu về giới, Khoa học máy tính, Khoa học thông tin và thư viện học, Quản ký và Kinh doanh, Y tế cộng đồng.

\section{Hình 2. Công bố của trung tâm ISR theo ngành}




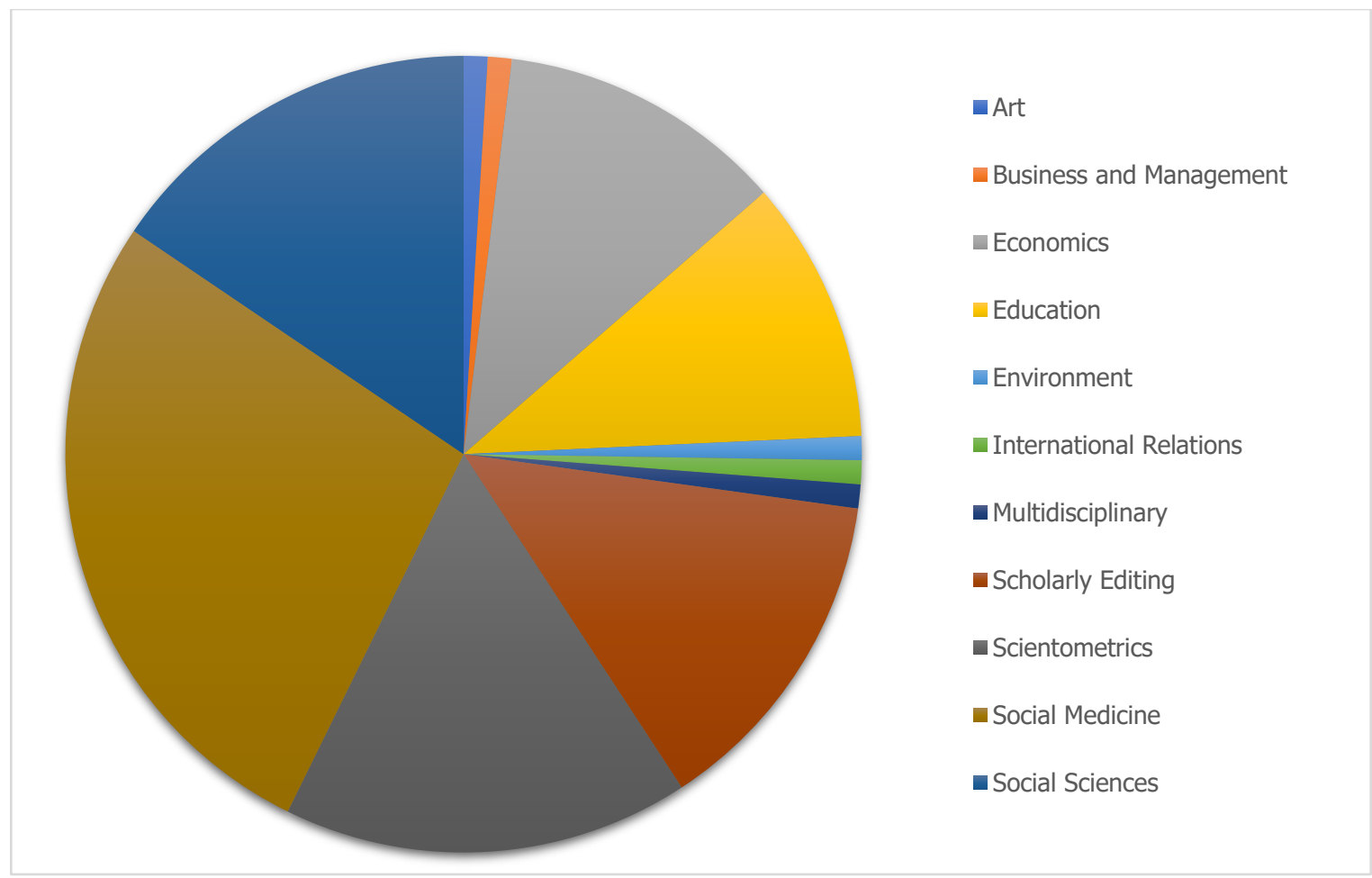

Xứng với cái tên, các nghiên cứu của trung tâm ISR đa dạng về chủ đề và chuyên ngành, từ kinh tế và giáo dục đến nghệ thuật và trắc lượng học (Hình 2). Xin lưu ý là một công bố có thể thuộc nhiều chuyên ngành khác nhau, nhưng chúng tôi chỉ để một chuyên ngành nổi bật nhất để trình bày tại đây. Với sự đa dạng này, chúng tôi đã có cơ hội hợp tác với các nhà khoa học có nhiêu chuyên ngành khác nhau, tới từ các trung tâm nghiên cứu hàng đâu như John Hopkins University (Hoa Kỳ), Science Po (Pháp), National University of Singapore (Singapore), Charles University (Séc), Đại học Ngoại thương và Viện Việt-Đức (Việt Nam).

Hơn 3 năm kể từ khi thành lập, nghiên cứu của trung tâm ISR đã cho thây giá trị đối với cộng đồng khoa học và xã hội. Ví dụ, nghiên cứu của một nhóm học giả từ Đại học Miami (Hoa Kỳ) giải thích tại sao người Mỹ lại tin vào các thuyết âm mưu Zika [106] đã sử dụng nghiên cứu của Vương Quân Hoàng về hiện tượng hiện nay dân chúng đang dần mất tin tưởng vào khoa học [8]. Cơ sở dữ liệu về các nhà khoa học xã hội của trung tâm cũng được sử dụng như là một ví dụ về dữ liệu mở $[107,108]$.

Năm 2020, Ủy ban Tài trợ Đại học Ấn Độ (hình 3) đã sử dụng bài blog trên LSE Impact $B \log [100]$ trong tài liệu hướng dẫn về các thông lệ học thuật tốt [109]. Giữa đại dịch COVID-19, bài nghiên cứu của chúng tôi về vai trò của truyền thông và truyền thông khoa học trong phòng chống và giảm thiểu tác hại của COVID-19 đã được phát hành kịp thời, làm tư liệu các nghiên cứu thuộc nhiều ngành khác như (ví dụ, chính sách y tế, giáo dục, kinh tế) [77]. Bài nghiên cứu đã được sử dụng để ủng hộ việc sử dụng truyền thông tốt sẽ là một chiến lược hiệu quả để chống lại COVID-19 và cải thiện niềm tin từ cộng đồng [110]. Một nghiên cứu khác sử dụng công bố của ISR về COVID-19 cũng cho rằng xây dựng chính sách tốt là điều bắt buộc phải có để ngăn ngừa sự lan rộng của COVID-19.

\section{Hình 3. Tài liệu hướng dẫn của Ủy ban Tài trợ Đại học Ấn Độ}




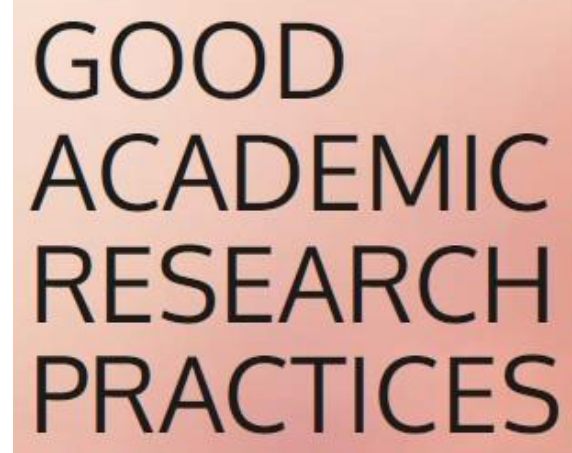

September 2020

Về việc nâng cao vai trò và hình ảnh của khoa học, đặc biệt là trong thời gian đại dịch bùng phát, một ấn phẩm của Royal Society of Canada (Viện Hàn lâm Khoa học Canada) đã sử dụng bài quan điểm của ISR trên Nature [86]. Bài trên đã đề xuất bốn bước để làm quá trình rút bài trở nên minh bạch hơn [112]. Sáng kiến trên nhân được sự chú ý của cộng đồng khoa học quốc tế, vì vậy đã được dịch ra bốn ngôn ngữ phổ biến: Tiếng Trung [113], tiếng Tây Ban Nha [115], tiếng Đức [116] và tiếng Nhật [114].

\section{Hình 4. Ấn phẩm của Royal Society of Canada [112]}




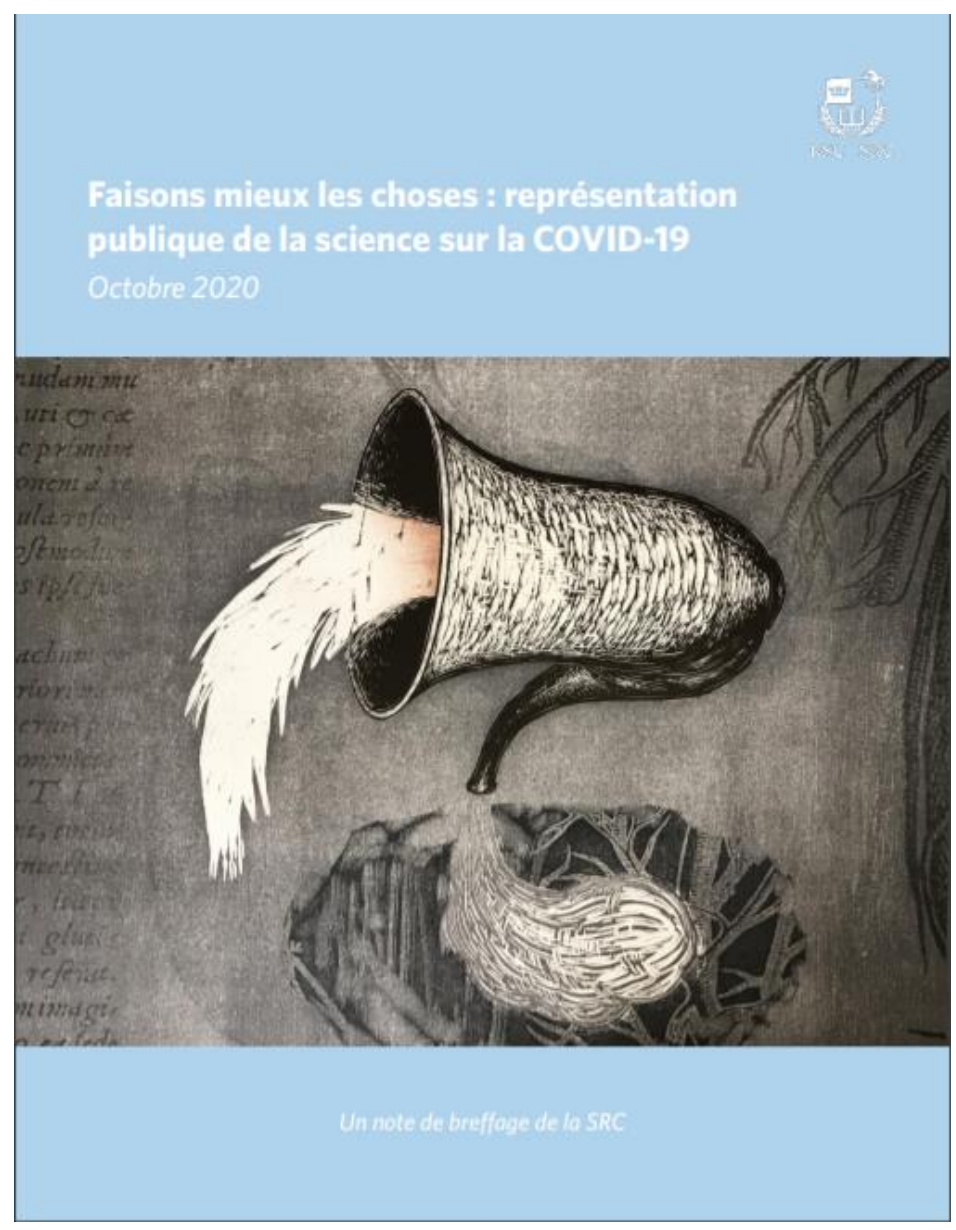

Sức lan tỏa khoa học còn có thể tìm thấy ở những công bố trước đây của cán bộ ISR. Năm 2019, chuỗi bài giảng DeVance của Đại học Yale, mang chủ đề "Quyền lực và Chính trị trên thễ giới ngày nay" đã sử dụng mà bài viêt vào năm 2014 của người sáng lập ISR [17]. Stratfor Worldview - một trang đưa tin về địa chính trị hàng đầu hiện nay - đã đăng bản ngắn gọn trên trang web của mình vào năm 2014 [18].

Hình 5. Chuỗi bài giảng DeVane năm 2019 của đại học Yale 


\section{Yale}

\section{DeVane Lectures: "Power and \\ Politics in Today's World”}

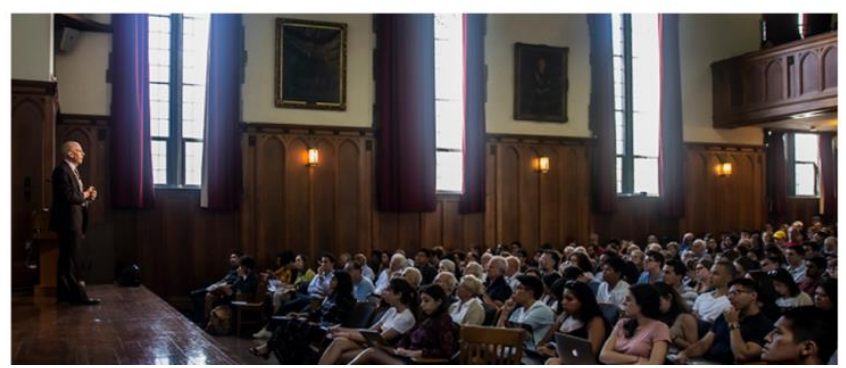

'Power and Politics' in the media

Yale News: Public invited to Professor Shapiro's 'Power and Politics' DeVane Lectures

YaleNews: Reflecting on Bretton Woods with Yale political scientist lan Shapire

The New York Times: Frances McCall Rosenbluth and lan Shapiro's tivate "Responsible Parties," and the test of U.K. democracy amidst Brexit

Ngoài ra, trong một vài năm qua, hai cơ sở dữ liệu , SSHPA và Scimath, đã được các cán bộ ISR trình làng. SSHPA là cơ sở dữ liệu ghi lại dữ liệu khoa học của các nhà nghiên cứu khoa học xã hội và nhân văn tại Việt Nam. Dự án này đã được tài trợ của Quỹ Phát triển khoa học và công nghệ Quốc Gia Việt Nam. Quá trình xây dựng và kiến trúc của cơ sở dữ liệu SSHPA đã được trình bày trên tập san Scientific Data của Nature Research [17]. Dữ liệu trích xuất từ SSHPA cũng được sử dụng trong các nghiên cứu của ISR [24, 85, 88]. Đây đều là các bài nghiên cứu gốc, nhằm tìm hiểu các khía cạnh khác nhau của ngành khoa học xã hội và nhân văn tại Việt Nam như năng xuất, quan hệ hợp tác và việc xuất bản mở.

Năm 2020 cũng chứng kiến tiến độ đáng mừng của cơ sở dữ liệu Scimath. Đây là một phân của dự án Phát triển Cơ sở dữ liệu Toán học Việt Nam được khởi sướng bởi GS. Ngô Bảo Châu (Viện nghiên cứu cao cấp về Toán - VIASM) và TS. Vương Quân Hoàng (Trung tâm ISR, AIDSL). Năm 2020, nhóm nghiên cứu đã có một buổi họp cùng với các đại diện từ VIASM để báo cáo tiến độ dự án. Kết quả là một bản báo cáo sơ bộ về quá trình phát triển toán học tại Việt Nam từ công bố quốc tế của Lê Văn Thiêm vào năm 1945 [118]. Nhóm nghiên cứu kỳ vọng sẽ giới thiệu cơ sở dữ liệu này với cộng đồng khoa học và công chúng trong tương lai gân.

\section{Hình 6. Buổi họp báo cáo tiến độ dự án đâu tiên với VIASM}




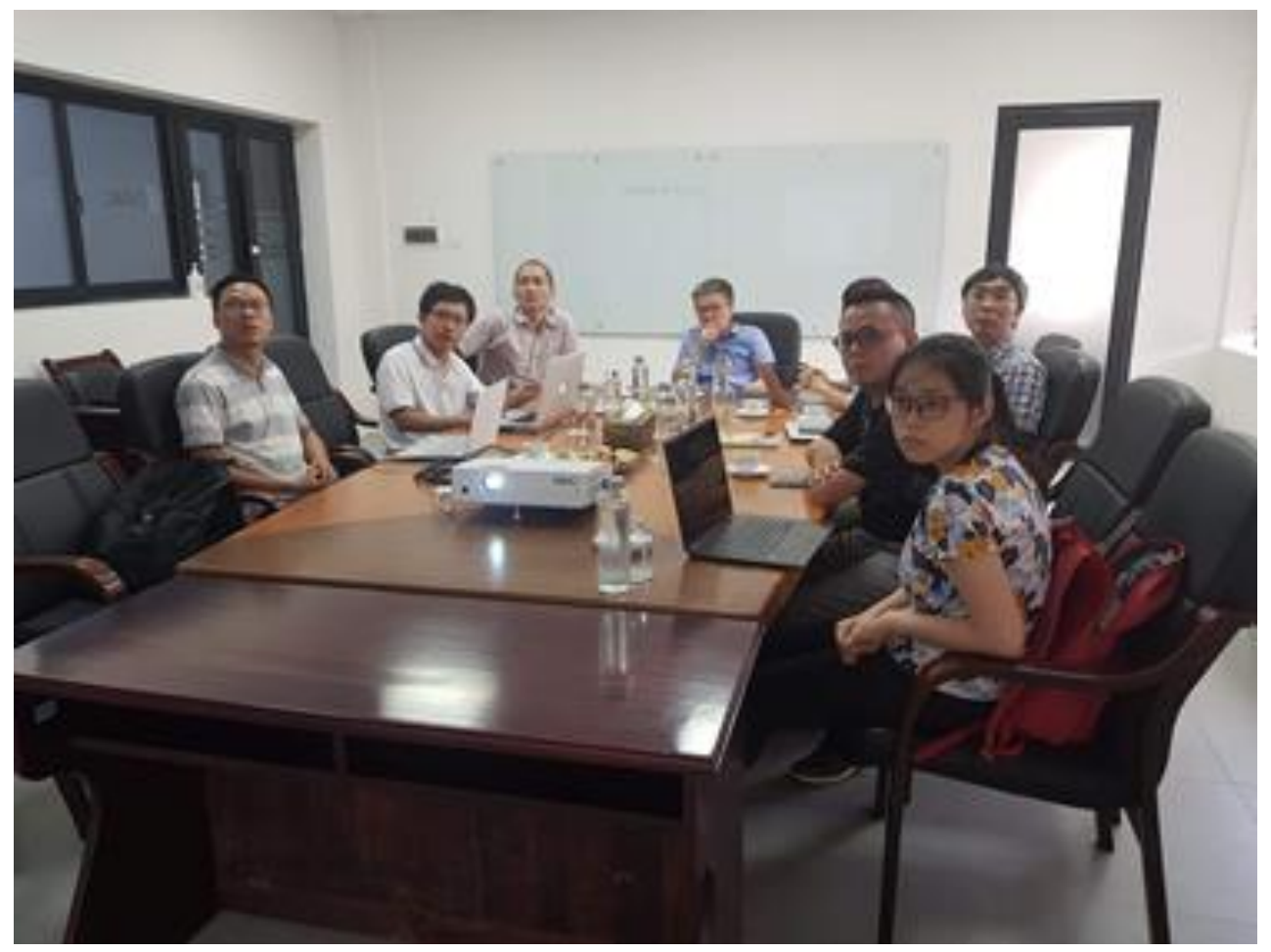

Công bố thứ 100 là một dấu mốc đặc biệt quan trọng. Nhìn lại những thành quả có được trong 1249 ngày qua, chúng tôi càng có thêm động lực để làm việc hăng say hơn. Chúng tôi biết rằng có rất nhiều kế hoạch và ý tưởng mới đang chờ gặt hái trong tương lai.

Các công bố được liệt kê ở phần Tài liệu tham khảo bên dưới.

Chúc mọi người một năm mới an lành!

\section{Tài liệu tham khảo}

1. Vuong, Q. H. (2017). Learning to love the reviewer. European Science Editing, 43(4), 83.

2. Ho, T. M., Nguyen, H. V., Vuong, T. T., Dam, Q. M., Pham, H. H., \& Vuong, Q. H. (2017). Exploring Vietnamese co-authorship patterns in social sciences with basic network measures of 2008-2017 Scopus data. F1000Research, 6, 1559.

3. Pekerti, A., Vuong, Q. H., Ho, T. M., \& Vuong, T. T. (2017). Health care payments in Vietnam: Patients' quagmire of caring for health versus economic destitution. International Journal of Environmental Research and Public Health, 14(10), 1118.

4. Vuong, Q. H., Ho, T. M., Vuong, T. T., Nguyen, H. V., Napier, N. K., \& Pham, H. H. (2017). Nemo solus satis sapit: Trends of research collaborations in the Vietnamese social sciences, observing 2008-2017 Scopus data. Publications, 5(4), 24.

5. Vuong, Q. H., Vuong, T. T., Ho, T. M., \& Nguyen, H. V. (2017). Psychological and socioeconomic factors affecting social sustainability through impacts on perceived health care quality and public health: The case of Vietnam. Sustainability, 9(8), 1456. 
6. Vuong, Q. H. (2017). Survey data on Vietnamese propensity to attend periodic general health examinations. Scientific Data, 4(1), 1-10.

7. Vuong, Q. H. (2017). Open data, open review and open dialogue in making social sciences plausible. Nature: Scientific Data Updates. URL: $<$ http://blogs.nature.com/scientificdata/2017/12/12/authors-corner-open-data-openreview-and-open-dialogue-in-making-social-sciences-plausible/>.

8. Vuong, Q. H. (2018). The (ir) rational consideration of the cost of science in transition economies. Nature Human Behaviour, 2(1), 5.

9. Vuong, Q. H. (2018). Sociodemographic factors influencing Vietnamese patient satisfaction with healthcare services and some meaningful empirical thresholds. Iranian Journal of Public Health, 47(1), 119.

10. Ho, T. M., Vuong, T. T., \& Vuong, Q. H. (2017). On the sustainability of co-authoring behaviors in Vietnamese social sciences: A preliminary analysis of network data. Sustainability, (11), 2142.

11. Vuong, T. T., Ho, T. M., Ho, T. M., \& Vuong, Q. H. (2018). The (in) significance of sociodemographic factors as possible determinants of Vietnamese social scientists' contribution-adjusted productivity: Preliminary results from 2008-2017 Scopus data. Societies, $8(1), 3$.

12. Ho, M. T., Nguyen, T. H. K., Ho, M. T., Vuong, T. T., \& Vuong, Q. H. (2018). To be human in the age of Industry 4.0: perspective from Vietnam. Proc. XXIV World Congress of Philosophy, Beijing 13-20 Aug. 2018. http://wcp2018.pku.edu.cn/yw/index.htm.

13. Vuong, Q. H., Ho, M. T., La, V. P., Vuong, T. T., Nguyen, T. H. K. (2018). How philosophy of social sciences can benefit from Bayesian statistics: Insights from a developing country. Proc. XXIV World Congress of Philosophy, Beijing 13-20 Aug. 2018. http://wcp2018.pku.edu.cn/yw/index.htm

14. Vuong, Q. H., Ho, T. M., Nguyen, H. K., \& Vuong, T. T. (2018). Healthcare consumers' sensitivity to costs: A reflection on behavioural economics from an emerging market. Palgrave Communications, 4(1), 1-10.

15. Tran, B. X., Pham, T. V., Ha, G. H., Ngo, A. T., Nguyen, L. H., Vu, T. T. M., ... \& Truong, N. T. (2018). A bibliometric analysis of the global research trend in child maltreatment. International Journal of Environmental Research and Public Health, 15(7), 1456.

16. Tran, B. X., Mai, H. T., Fleming, M., Do, H. N., Nguyen, T. M. T., Vuong, Q. H., ... \& Truong, N. T. (2018). Factors associated with substance use and sexual behavior among drug users in three mountainous provinces of Vietnam. International Journal of Environmental Research and Public Health, 15(9), 1885.

17. Vuong, Q. H., La, V. P., Vuong, T. T., Ho, M. T., Nguyen, H. K. T., Nguyen, V. H., ... \& Ho, M. T. (2018). An open database of productivity in Vietnam's social sciences and humanities for public use. Scientific Data, 5, 180188.

18. Vuong, Q. H., Ho, M. T., Vuong, T. T., Tran, K., \& Ho, M. T. (2018). "Paintings can be forged, but not feeling": Vietnamese art-market, fraud, and value. Arts, 74$), 62$.

19. Vuong, Q. H., Hoang, A. D., Vuong, T. T., La, V. P., \& Ho, M. T. (2018). Factors associated with the regularity of physical exercises as a means of improving the public health system in Vietnam. Sustainability, 10(11), 3828. 
20. Khuat, T. H., Do, T. T., Nguyen, V. A. T., Vu, X. T., Nguyen, P. T. T., Tran, K., ... \& Vuong, Q. H. (2018). The dark side of female HIV patient care: Sexual and reproductive health risks in pre-and post-clinical treatments. Journal of Clinical Medicine, $\pi 11), 402$.

21. Nguyen, T. M. T., Tran, B. X., Fleming, M., Pham, M. D., Nguyen, L. T., Le, H. T., ... \& Vuong, Q. H. (2018). Methadone maintenance treatment reduces the vulnerability of drug users on HIV/AIDS in Vietnamese remote settings: Assessing the changes in HIV knowledge, perceived risk, and testing uptake after a 12-month follow-up. International Journal of Environmental Research and Public Health, 15(11), 2567.

22. Vuong, Q. H., Bui, Q. K., La, V. P., Vuong, T. T., Nguyen, V. H. T., Ho, M. T., ... \& Ho, M. T. (2018). Cultural additivity: behavioural insights from the interaction of Confucianism, Buddhism and Taoism in folktales. Palgrave Communications, 4(1), 143.

23. Tran, B. X., Nguyen, Q. N., Dang, A. K., Vu, G. T., Hoang, V. Q., La, P. V., ... \& Le, H. T. (2018). Acceptability of and willingness to pay for using a smartphone-based vaccination application in a Vietnamese cohort. Patient Preference and Adherence, 12, 2583.

24. Vuong, Q. H., Napier, N. K., Ho, T. M., Nguyen, V. H., Vuong, T. T., Pham, H. H., \& Nguyen, H. K. T. (2019). Effects of work environment and collaboration on research productivity in Vietnamese social sciences: evidence from 2008 to 2017 Scopus data. Studies in Higher Education, 44(12), 2132-2147.

25. Ho, M. T., \& Vuong, Q. H. (2019). The values and challenges of 'openness' in addressing the reproducibility crisis and regaining public trust in social sciences and humanities. European Science Editing, 45(1), 14-17.

26. Nguyen, T. M. T., Tran, B. X., Fleming, M., Pham, M. D., Nguyen, L. T., Nguyen, A. L. T., ... \& Ho, M. T. (2019). HIV knowledge and risk behaviors among drug users in three Vietnamese mountainous provinces. Substance Abuse Treatment, Prevention, and Policy, 14(1), 1-8.

27. Nguyen, V. A. T., Nguyen, N. Q. H., Khuat, T. H., Nguyen, P. T. T., Do, T. T., Vu, X. T., ,.. \& Vuong, Q. H. (2019). Righting the Misperceptions of Men Having Sex with Men: A PreRequisite for Protecting and Understanding Gender Incongruence in Vietnam. Journal of Clinical Medicine, 8(1), 105.

28. Vuong, Q. H., Nghiem, K. C. P., La, V. P., Vuong, T. T., Ho, M. T., Tran, K., ... \& Ho, M. T. (2019). Sex differences and psychological factors associated with general health examinations participation: Results from a Vietnamese cross-section dataset. Sustainability, 11(2), 514.

29. Tran, B. X., Nguyen, L. H., Vu, G. T., Le, H. T., Nguyen, H. D., Hoang, V. Q., ... \& Nguyen, H. L. T. (2019). Online peer influences are associated with receptiveness of youths: The case of Shisha in Vietnam. Children and Youth Services Review, 99, 18-22.

30. Vuong, Q. H., Ho, M. T., Vuong, T. T., La, V. P., Ho, M. T., Nghiem, K. C. P., ... \& Ho, C. S. (2019). Artificial intelligence vs. natural stupidity: Evaluating AI readiness for the Vietnamese medical information system. Journal of Clinical Medicine, 8(2), 168.

31. Hoang, C. D., Tran, B. X., Pham, M. D., Nguyen, L. H., Do, H. N., Vuong, Q. H., ... \& Pham, H. Q. (2019). HIV-and AIDS-related knowledge and attitude of residents in border regions of Vietnam. Harm Reduction Journal, 16(1), 11.

32. Vuong, Q. H. (2019). SciRev: an initiative for improving peer review transparency. European Science Editing, 45(1), 20. 
33. Vuong, Q. H. (2019). Computational entrepreneurship: From economic complexities to interdisciplinary research. Problems and Perspectives in Management, 171), 117-129.

34. Pham, H. H., Lai, S. L., \& Vuong, Q. H. (2019). The Role of Subjective Task Value in Forming Satisfaction and Loyalty Among Vietnamese International Students: A Structural Equation Model. The Asia-Pacific Education Researcher, 28(5), 399-409.

35. Tran, B. X., Vu, G. T., Ha, G. H., Vuong, Q. H., Ho, M. T., Vuong, T. T., ... \& Latkin, C. A. (2019). Global evolution of research in artificial intelligence in health and medicine: a bibliometric study. Journal of Clinical Medicine, 8(3), 360.

36. Nguyen, M. H., Serik, M., Vuong, T. T., \& Ho, M. T. (2019). Internationalization and its discontents: Help-seeking behaviors of students in a multicultural environment regarding acculturative stress and depression. Sustainability, 11(7), 1865.

37. Vuong, Q. H., Le, A. V., La, V. P., Vuong, T. T., Do, T. H., Vuong, H. M., ... \& Ho, M. T. (2019). A Dataset of Vietnamese junior high school students' reading preferences and habits. Data, 4(2), 49.

38. Vu, T. H., Nguyen, V. D., Ho, M. T., \& Vuong, Q. H. (2019). Determinants of Vietnamese listed firm performance: Competition, wage, CEO, firm size, age, and international trade. Journal of Risk and Financial Management, 12(2), 62.

39. Ho, M. T., La, V. P., Nguyen, M. H., Vuong, T. T., Nghiem, K. C. P., Tran, T., \& Vuong, Q. H. (2019). Health Care, medical insurance, and economic destitution: A dataset of 1042 stories. Data, 4(2), 57.

40. Pham, K. T. H., Nguyen, L. H., Vuong, Q. H., Ho, M. T., Vuong, T. T., Vu, G. T., ... \& Ho, R. (2019). Health inequality between migrant and Non-Migrant workers in an industrial zone of Vietnam. International Journal of Environmental Research and Public Health, 16(9), 1502.

41. Vuong, Q. H., Ho, T. M., \& La, V. P. (2019). 'Stargazing' and p-hacking behaviours in social sciences: some insights from a developing country. European Science Editing, 45(2), 5657.

42. Tran, B. X., Vu, G. T., Pham, K. T. H., Vuong, Q. H., Ho, M. T., Vuong, T. T., ... \& Ho, R. (2019). Depressive Symptoms among industrial workers in Vietnam and correlated factors: A multi-site survey. International Journal of Environmental Research and Public Health, 16(9), 1642.

43. Le, A. V., Do, D. L., Pham, D. Q., Hoang, P. H., Duong, T. H., Nguyen, H. N., ... \& Vuong, Q. H. (2019). Exploration of youth's digital competencies: a dataset in the educational context of Vietnam. Data, 4(2), 69.

44. Thao, T. T. P., Thai, L. D., Thanh, H. T., Tran, T., \& Vuong, Q. H. (2019). Mobile learning for high-school mathematics as a path to better sustainability in a fast-changing society: An exploratory study from Vietnam. Problems and Perspectives in Management, 17(2), 392-403.

45. Vuong, Q. H., Vuong, T. T., \& Ho, M. T. (2019). The 'same bed, different dreams' of Vietnam and China: how (mis)trust could make or break it. European Journal of East Asian Studies, 18(1), 93-128.

46. Ho, H. H., Vu, T. H., Dao, N. T., Ho, M. T., \& Vuong, Q. H. (2019). When the Poor Buy the Rich: New Evidence on Wealth Effects of Cross-Border Acquisitions. Journal of Risk and Financial Management, 12(2), 102. 
47. Nguyen, V. H. T., Vuong, T. T., Ho, M. T., \& Vuong, Q. H. (2019). The new politics of debt in the transition economy of Vietnam. Austrian Journal of South-East Asian Studies, 12(1), $91-110$.

48. Tran, B. X., Fleming, M., Nguyen, T. M. T., Vu, G. T., Vuong, Q. H., Ho, M. T., ... \& Latkin, C. (2019). Changes in substance abuse and HIV risk behaviors over 12-month methadone maintenance treatment among Vietnamese patients in mountainous provinces. International Journal of Environmental Research and Public Health, 16(13), 2422.

49. Nguyen, T. D., \& Ho, M. T. (2019). People as the Roots (of the State): Democratic Elements in the Politics of Traditional Vietnamese Confucianism. Journal of Nationalism, Memory \& Language Politics, 13(1), 90-110.

50. Vuong, Q. H. (2019). The harsh world of publishing in emerging regions and implications for editors and publishers: The case of Vietnam. Learned Publishing, 32(4), 314-324.

51. Tran, T., Le, T. T. H., Nguyen, T. T., Pham, A. G., Vu, T. H., Nguyen, M. H., ... \& Vuong, Q. H. (2019). The relationship between birth order, sex, home scholarly culture and youths' reading practices in promoting lifelong learning for sustainable development in Vietnam. Sustainability, 11(16), 4389.

52. Nguyen, M. H., Ho, M. T., Nguyen, Q. Y. T., \& Vuong, Q. H. (2019). A dataset of students' mental health and help-seeking behaviors in a multicultural environment. Data, 4(3), 124.

53. Vuong, Q. H., Bui, Q. K., La, V. P., Vuong, T. T., Ho, M. T., Nguyen, H. K. T., ... \& Ho, M. T. (2019). Cultural evolution in Vietnam's early 20th century: A Bayesian networks analysis of Hanoi Franco-Chinese house designs. Social Sciences \& Humanities Open, 1(1), 100001.

54. Le, T. A., Pham, D. T., Quek, T. T., Vu, G. T., Hoang, C. L., Tran, T. T., ... \& Tran, B. X. (2019). Polysubstance use among patients enrolling in methadone maintenance treatment program in a Vietnam province with drug-driven HIV epidemic. International Journal of Environmental Research and Public Health, 16(18), 3277.

55. Le, T. T. H., Tran, T., Trinh, T. P. T., Nguyen, C. T., Nguyen, T. P. T., Vuong, T. T., ... \& Nguyen, M. H. (2019). Reading habits, socioeconomic conditions, occupational aspiration and academic achievement in Vietnamese junior high school students. Sustainability, 11(18), 5113.

56. Le, T. A., Le, M. Q. T., Dang, A. D., Dang, A. K., Nguyen, C. T., Pham, H. Q., ... \& Tran, T. H. (2019). Multi-level predictors of psychological problems among methadone maintenance treatment patients in different types of settings in Vietnam. Substance Abuse Treatment, Prevention, and Policy, 14(1), 39.

57. Vuong, Q. H. (2019). Breaking barriers in publishing demands a proactive attitude. Nature Human Behaviour, 3(10), 1034-1034.

58. Ho, M. T., Vuong, T. T., Nguyen, M. H., \& Ho, T. (2019). To Walk on the Penrose Stairs of Science. Behavioural and Social Sciences. URL: https://socialsciences.nature.com/ channels/2140-is-it-publish-or-perish/posts/54541-to-walk-on-the-penrose-stairs-ofscience>.

59. Vuong, Q. H., Vu, T. H., Doan, Q. H., \& Ho, M. T. (2019). Determinants of Vietnamese footwear exporting firms' market selection: A multinomial logistic analysis of panel data. Heliyon, 5(10), e02582.

60. Vuong, Q. H., \& Tran, T. (Ed.) (2019). The Vietnamese Social Sciences at a Fork in the Road. Warsaw, Poland: De Gruyter (Edition: Sciendo). DOI: 10.2478/9783110686081. 
61. Nguyen, T. T., La, V. P., Ho, M. T., \& Nguyen, H. K. T. (2019). Scientific publishing: a slow but steady rise. In: Vuong, Q. H., \& Tran, T. (Eds.) The Vietnamese Social Sciences at a Fork in the Road (pp. 33-51). Warsaw, Poland: De Gruyter. DOI: 10.2478/9783110686081-007.

62. Le, T. H. T., Pham, H. H., La, V. P., \& Vuong, Q. H. (2019). The faster-growing fields. In: Vuong, Q. H., \& Tran, T. (Eds.) The Vietnamese Social Sciences at a Fork in the Road (pp. 52-79). Warsaw, Poland: De Gruyter. DOI: 10.2478/9783110686081-008.

63. Doan, X. H., Nguyen, P. T. T., La, V. P., \& Nguyen, H. K. T. (2019). Researchers who lead the trends. In: Vuong, Q. H., \& Tran, T. (Eds.) The Vietnamese Social Sciences at a Fork in the Road (pp. 98-120). Warsaw, Poland: De Gruyter. DOI: 10.2478/9783110686081010.

64. Nguyen, H. K. T., Nguyen, T. H. T., Ho, M. T., Ho, M. T., \& Vuong, Q. H. (2019). Scientific publishing: the point of no return. In: Vuong, Q. H., \& Tran, T. (Eds.) The Vietnamese Social Sciences at a Fork in the Road (pp. 143-162). Warsaw, Poland: De Gruyter. DOI: 10.2478/9783110686081-012.

65. Ho, M. T., Hoang, K. L., Nguyen, M. H., \& Ho, M. T. (2019). The emerging business of science in Vietnam. In: Vuong, Q. H., \& Tran, T. (Eds.) The Vietnamese Social Sciences at a Fork in the Road (pp. 163-177). Warsaw, Poland: De Gruyter. DOI: 10.2478/9783110686081-013.

66. Vuong, Q. H., \& Tran, T. (2019). Closing remarks. In: Vuong, Q. H., \& Tran, T. (Eds.) The Vietnamese Social Sciences at a Fork in the Road (pp. 178-180). Warsaw, Poland: De Gruyter. DOI: 10.2478/9783110686081-014.

67. Vuong, Q. H., Ho, M. T., Nguyen, H. K. T., \& Nguyen, M. H. (2019). The trilemma of sustainable industrial growth: Evidence from a piloting OECD's Green city. Palgrave Communications, 5(1), 156.

68. Vuong, Q. H. (2020). The limitations of retraction notices and the heroic acts of authors who correct the scholarly record: An analysis of retractions of papers published from 1975 to 2019. Learned Publishing, 33(2), 119-130.

69. Vuong, Q. H. (2020). Plan S, self-publishing, and addressing unreasonable risks of society publishing. Learned Publishing, 33(1), 64-68.

70. Tran, T., Hoang, K. L., La, V. P., Ho, M. T., \& Vuong, Q. H. (2020). Scrambling for higher metrics in the Journal Impact Factor bubble period: a real-world problem in science management and its implications. Problems and Perspectives in Management, 18(1), 4856.

71. Ngo, C. Q., Vu, G. V., Phan, P. T., Chu, H. T., Doan, L. P. T., Duong, A. T., ... \& Ha, G. H. (2020). Passive Smoking Exposure and Perceived Health Status in Children Seeking Pediatric Care Services at a Vietnamese Tertiary Hospital. International Journal of Environmental Research and Public Health, 17(4), 1188.

72. Nguyen, M. H., Ho, M. T., La, V. P., Nguyen, Q. Y. T., Ho, M. T., Vuong, T. T., ... \& Vuong, Q. H. (2020). A Scientometric Study on Depression among University Students in East Asia: Research and System Insufficiencies?. Sustainability, 12(4), 1498.

73. Vuong, Q. H., La, V. P., Ho, M. T., Vuong, T. T., \& Ho, M. T. (2020). Characteristics of retracted articles based on retraction data from online sources through February 2019. Science Editing, 71$), 34-44$. 
74. Vuong, Q. H. (2020). The rise of preprints and their value in social sciences and humanities. Science Editing, $\nearrow 1$, 70-72.

75. Vuong, Q. H., Le, A. V., La, V. P., Hoang, P. H., \& Ho, M. T. (2020). Making social sciences more scientific: Literature review by structured data. MethodsX, 7, 100818.

76. Tran, B. X., Moir, M., Nguyen, T. M. T., Do, H. N., Vu, G. T., Dang, A. K., .. \& Van Dam, N. (2020). Changes in quality of life and its associated factors among illicit drug users in Vietnamese mountainous provinces: a 12-month follow-up study. Substance Abuse Treatment, Prevention, and Policy, 15(1), 1-8.

77. La, V. P., Pham, T. H., Ho, M. T., Nguyen, M. H., P Nguyen, K. L., Vuong, T. T., ... \& Vuong, Q. H. (2020). Policy response, social media and science journalism for the sustainability of the public health system amid the COVID-19 outbreak: The Vietnam lessons. Sustainability, 12(7), 2931.

78. Vuong, Q. H., La, V. P., Vuong, T. T., Hoang, P. H., Ho, M. T., \& Ho, M. T. (2020). Multifaceted insights of entrepreneurship facing a fast-growing economy: A literature review. Open Economics, 3(1), 25-41.

79. Vuong, Q. H., La, V. P., Vuong, T. T., Nguyen, H. K. T., Ho, M. T., \& Ho, M. T. (2020). What have Vietnamese scholars learned from researching entrepreneurship? A systematic review. Heliyon, 6(4), e03808.

80. Vuong, Q. H., La, V. P., Nguyen, M. H., Ho, M. T., Ho, M. T., \& Mantello, P. (2020). Improving Bayesian statistics understanding in the age of Big Data with the bayesvl $\mathrm{R}$ package. Software Impacts, 4, 100016.

81. Tran, T., Ho, M. T., Pham, T. H., Nguyen, M. H., Nguyen, K. L. P., Vuong, T. T., ... \& La, V. P. (2020). How digital natives learn and thrive in the digital age: Evidence from an emerging economy. Sustainability, 12(9), 3819.

82. Vuong, Q. H., Ho, M. T., Nguyen, H. K. T., Vuong, T. T., Tran, T., Hoang, K. L., ... \& La, V. P. (2020). On how religions could accidentally incite lies and violence: Folktales as a cultural transmitter. Palgrave Communications, 6(1), 82.

83. Vuong, Q. H., La, V. P., Nguyen, M. H., Ho, M. T., Tran, T., \& Ho, M. T. (2020). Bayesian analysis for social data: A step-by-step protocol and interpretation. MethodsX, 7, 100924.

84. Giang, T. L., Vo, D. T., \& Vuong, Q. H. (2020). COVID-19: A Relook at Healthcare Systems and Aged Populations. Sustainability, 12(10), 4200.

85. Ho, M. T., Vuong, T. T., Pham, T. H., Luong, A. P., Nguyen, T. N., \& Vuong, Q. H. (2020). The Internal Capability of Vietnam Social Sciences and Humanities: A Perspective from the 2008-2019 Dataset. Publications, 8(2), 32.

86. Vuong, Q. H. (2020). Reform retractions to make them more transparent. Nature, 582(7811), 149.

87. Pham, T. H., Ho, M. T., Vuong, T. T., Nguyen, M. C., \& Vuong, Q. H. (2020). Entrepreneurial Finance: Insights from English Language Training Market in Vietnam. Journal of Risk and Financial Management, 13(5), 96.

88. Vuong, T. T., Ho, M. T., Nguyen, M. H., Nguyen, T. H. T., Nguyen, T. D., Nguyen, T. L., ... \& Vuong, Q. H. (2020). Adopting open access in the social sciences and humanities: evidence from a developing nation. Heliyon, 6(7), e04522.

89. Hoang, A. D., Pham, H. H., Nguyen, Y. C., Vuong, Q. H., Dam, M. Q., Tran, T., \& Nguyen, T. T. (2020). Introducing a tool to gauge curriculum quality under Sustainable 
Development Goal 4: The case of primary schools in Vietnam. International Review of Education, 66(4), 457-485.

90. Vuong, Q. H., La, V. P., Ho, M. T., Trang, V. T., \& Ho, M. T. (2020). Identifying the moralpractical gaps in corporate social responsibility missions of Vietnamese firms: an eventbased analysis of sustainability feasibility. Corporate Social Responsibility and Environmental Management, 27, EarlyView, doi:10.1002/csr.2029.

91. Ho, M. T., La, V. P., Nguyen, M. H., Pham, T. H., Vuong, T. T., Vuong, H. M., ... \& Vuong, Q. H. (2020). An analytical view on STEM education and outcomes: Examples of the social gap and gender disparity in Vietnam. Children and Youth Services Review, 119, 105650.

92. Vuong, Q. H., \& Ho, M. T. (2020). Rethinking editorial management and productivity in the COVID-19 pandemic. European Science Editing, 46, e56541.

93. Vuong, Q. H. (2020). An Unprecedented Time for Entrepreneurial Finance upon the Arrival of Industry 4.0. Journal of Risk and Financial Management, 13(10), 224.

94. Nguyen, T. T. H., Pham, H. H., Vuong, Q. H., Cao, Q. T., Dinh, V. H., \& Nguyen, D. D. (2020). The adoption of international publishing within Vietnamese academia from 1986 to 2020: A review. Learned Publishing, EarlyView, doi: 10.1002/leap.1340.

95. Nguyen, H. K. \& Ho, T. M. (2020). Vietnam's COVID-19 Strategy: Mobilizing Public Compliance Via Accurate and Credible Communications. ISEAS Perspective, 69, 1-15.

96. Vuong, Q. H., La, V. P., Vuong, T. T., \& Ho, M. T. (2020). Earth Hour in Vietnam: a perspective from the electricity industry. Nature: Behavioural \& Social Sciences. Available from: https://go.nature.com/3eGzl6Y.

97. Vuong, Q. H. (Ed.). (2020). Entrepreneurial Finance at the Dawn of Industry 4.0. Basel, Switzerland: MDPI AG. DOI:10.3390/books978-3-03943-598-2

98. Vuong, Q. H., Pham, H. (2020). Accelerating social sciences reach a fork in the road. University World News. Retrieved from https://www.universityworldnews.com/ post.php?story $=20201118123527565$

99. Vuong, Q. H. (2020). ¿Cómo retractarse en ciencia?. Investigación y Ciencia, № 530 (Noviembre 2020). URL: https://www.investigacionyciencia.es/revistas/investigacion-yciencia/grandes-hitos-y-prximos-retos-de-la-ciencia-811/cmo-retractarse-en-ciencia$\underline{19145}$

100. Vuong, Q. H. (2020). Retractions: the good, the bad, and the ugly. What researchers stand to gain from taking more care to understand errors in the scientific record. LSE Impact of Social Sciences. Retrieved from: https://blogs.Ise.ac.uk/impactofsocialsciences/2020/02/20/ retractions-the-good-thebad-and-the-ugly-what-researchers-stand-to-gain-from-taking-more-care-to-understanderrors-in-the-scientific-record/

101. Nguyen, M. H., Pham, T. H., Ho, M. T., Nguyen, H. T. T., \& Vuong, Q. H. (2020). On the social and conceptual structure of the 50 -year research landscape in entrepreneurial finance. SN Business \& Economics, 1(1), 1-29.

102. Vuong, Q. H. (2021). From children's literature to sustainability science, and young scientists for a more sustainable Earth. Journal of Sustainability Education, 24: in-press.

103. Ho, M. T., Progler, J., \& Vuong, Q. H. (2021). Anatomy of contemporary Vietnamese satirical cartoons: Political communication and representation of systemic corruption. Asian Studies Review, 44, forthcoming. 
104. Vuong, Q. H., Bui, A. T., La, V. P., Nguyen, M. H., Pham, H. H., Pham, T. H., Vu, T. H., Vuong, T. T., \& Ho, M. T. (2021). Mirror, mirror on the wall: Is economics the fairest of them all? An investigation into the social sciences and humanities in Vietnam. Research Evaluation, 30, in-press, DOI:10.1093/reseval/rvaa036.

105. La, V. P., \& Vuong, Q. H. (2019). bayesvl: Visually learning the graphical structure of Bayesian networks and performing MCMC with 'Stan'. The Comprehensive $R$ Archive Network (CRAN). https://cran.r-project.org/package=bayesvl

106. Klofstad, C. A., Uscinski, J. E., Connolly, J. M., \& West, J. P. (2019). What drives people to believe in Zika conspiracy theories?. Palgrave Communications, 5(1), 36. doi:10.1057/s41599-019-0243-8

107. Li, J., Yin, Y., Fortunato, S., \& Wang, D. (2019). A dataset of publication records for Nobel laureates. Scientific Data, 6(1), 1-10.

108. Li, J., Yin, Y., Fortunato, S., \& Wang, D. (2020). Scientific elite revisited: patterns of productivity, collaboration, authorship and impact. Journal of the Royal Society Interface, 17165), 20200135.

109. Patwardhan B., Desai A., Chourasia A, Nag S., Bhatnagar R. (2020). Guidance Document: Good Academic Research Practices. New Delhi: University Grants Commission. Retrieved from:

https://www.ugc.ac.in/ebook/UGC_GARP_2020_Good\%20Academic\%20Research\%20Pr actices.pdf.

110. Marianne, U. P., Paula, M. L. (2020). Trust in Public Health Is Essential Amid the COVID19 Pandemic. Journal of Hospital Medicine, 7, 431-433.

111. Oehmke, J. F., Moss, C. B., Singh, L. N., Oehmke, T. B., Post, L. A. (2020). Dynamic Panel Surveillance of COVID-19 Transmission in the United States to Inform Health Policy: Observational Statistical Study. Journal of Medical Internet Research, 22(10), e21955

112. Tania, B., Timothy, C., Jonathan, K., Vardit, R., (2020) Faisons mieux les choses : représentation publique de la science sur la COVID-19. Société royale du Canada. Retrieved from: https://rsc-src.ca/fr/covid-19-policy-briefing/faisons-mieux-les-chosesrepr\%C3\%A9sentation-publique-de-la-science-sur-la-covid.

113. Quan-Hoang Vuong. (2020). 論文撤回を改革して透明性を高めよ. Nature ダイジェスト , 17( 8), doi:10.1038/ndigest.2020.200818.

114. 李晨阳，徐竞然 (2020). 要撤稿? 请交代清楚这 4 点! 中国科学报社 (June 9). http://news.sciencenet.cn/htmlnews/2020/6/441196.shtm

115. Michael Springer (2020). Selbstkontrolle mit kleinen Fehlern. Spektrum der Wissenschaft (October 26). *URL: https://www.spektrum.de/kolumne/luecken-im-peer-reviewprozess $/ 1771644$

116. Yale University. (2019). 2019 DeVane Lectures: "Power and Politics in Today's World". Yale University web page. https://communications.yale.edu/2019-devane-lecturespower-and-politics-todays-world

117. Vuong, Quan-Hoang. (2014). Vietnam's political economy in transition (1986-2016). Stratfor-The Hub: International Perspectives. https://worldview.stratfor.com/article/vietnams-political-economytransition-1986-2016 
118. Chau, N. B., Hoang, V. Q., Phuong, L. V., Hoa, L. T., Ha, L. M., Giang, T. T. T., ... \& Trung, T. (2020). The 80-year development of Vietnam mathematical research: Preliminary insights from the SciMath database on mathematicians, their works and their networks. arXiv preprint arXiv:2011.09328. 